\title{
The Use of Students' Oral Presentation in Enhancing Students' Response in Teaching Reading
}

\author{
Zahratul Fikni ${ }^{1)}$, Ari Prasetya Ningrum ${ }^{2)}$ \\ ${ }^{1}$ Universitas Hamzanwadi \\ zahratulfiknii@gmail.com, \\ ${ }^{2}$ Universitas Hamzanwadi \\ rheafanny1981@gmail.com
}

Received: $23^{\text {rd }}$ May 2021, Revised: $28^{\text {th }}$ June 2021, Accepted: $29^{\text {th }}$ June 2021

Email Correspondence: zahratulfiknii@gmail.com

\begin{abstract}
This study was aimed to know is there an effect of the use of students' oral presentation in enhancing students' response in teaching reading. The research design of this study used preexperimental in one group pretest - posttest design to know students' response in teaching reading. Pre-test was administrated at the first meeting before teaching them by using each of the defined techniques for the students and post-test was given to the students at the same test after completing the treatment. Then, the researcher analyzed and compared the result of the pre test and posts test to measure the independent variable. The participants of the research were the eleventh grade of SMAN 1 Suralaga, consists of 30 students. The research instrument used by the writer was oral question. The researcher asked the students to give respond based on the text given. This was aimed at knowing the students respond toward the reading text. After the data were collected, the researcher then analyzed them by using $t$ test formula. The finding of the research showed that: mean score of pre test was 15.22, while mean score of post test was 20.87 , and observed was 6.94. The table with $\mathrm{df}=\mathrm{n}-1 \quad(35-1=34)$ and significance level at 0.05 was 2.31. It is means that the treatment by using students' oral presentation in enhancing students' respond in reading text, there was a positive effect to students' response in teaching reading.
\end{abstract}

Keywords: oral presentation, students' response, teaching reading

\section{INTRODUCTION}

English is a means of communication which plays a very significance role as an international language (Matsuda, 2017). Almost all aspects of life in the world need English. The international events such as workshop, conferences, and trades mostly use English as the means of communication. By mastering English, people can go anywhere and enable them to interact with the other people in the whole parts of the word. English is also needed when the people want to get jobs for their livelihood.

Based on the facts, English is absolutely needed by almost people in the world. Therefore, all countries oblige English subject as one of compulsory subject in their education curriculum system. In Indonesia, English is learnt as a foreign language subject in every level from junior high school to the university. Even at the present time, English is taught since the earlier time in the elementary school

Online at https://journal.universitasbumigora.ac.id/index.php/humanitatis/

DOI $\quad$ : https://doi.org/10.30812/humanitatis.v7i2.1226 
level(Sepyanda, 2017). This is aimed at enabling the students to learn and communicate English in the earlier age in order that they will be much better in the future.

Haerudin, Koswara, \& Sejati ( 2021) state that English language teaching in the level of junior high school (SMP/MTs), and senior high school (SMA/MA) is concerned on four language skills which are called listening, speaking, reading, and writing skill. All of the four language skill can nor be taught separately, but they must be integrated in teaching and learning process at once. Teacher should decide which one of the skills that must be stressed in a meeting.

Conducting this research, the researcher firstly observed the condition of the school where the research was conducted. In the observation, the researcher found that there were some students who get difficulties to understand the instruction that given by the teacher. The students were difficult to do some tasks which related to reading comprehensions. So in this study the researcher would like to investigatestudents' oral presentation in enhancing students' response in teaching reading.

In this study, the researcher saw that the problem which usually face by the most of the students when they were taught reading text(Anderson, 2018). The students was difficult to give the opinions or respond toward what they read in the text, they cannot find the messages that presented on the text itself, they do not know how to look for ideas that delivered by the text.

Pondering above problems, the researcher used students' oral presentation to overcome the problems. Students' oral presentation is a test that given to the students orally(Toro, Camacho-Minuche, Pinza-Tapia, \& Paredes, 2019). The test is about the material that will be delivered to the students. In this study, the researcher gave the students some reading text, then the students analyzed the text, after analyzing the text, the researcher gave some questions that related to the text.

The students' oral presentation is aimed at engaging the students' motivation to think critically and creatively in searching the messages in the reading text. By the orally oral presentation of the students, they are more creative and critical to give respond toward what they have read in the text given by the teacher(Gilles, Wang, Smith, \& Johnson, 2013). As result, the students can give good respond for the text because of the helping of the oral presentation. The students are wished to be able to express their opinion related to the text by giving oral presentation. They can think critically in order that they can find the ideas in the reading text material.

Based on the explanation in the above, statement of problem of the research was is there any effect of the students' oral in enhancing students' response in teaching reading for the eleventh grade of SMAN 1 Suralaga in the school year of 2019/2020. 


\section{RESEARCH METHOD}

Moser \& Korstjens (2018) states that research design is basic plan, which guides the data collection and analysis phases of the project. This research was categorized into an experimental research. (Merriam \& Tisdell, 2015)says that experimental is a procedure in quantitative research which the investigator determines whether an activity or material makes a difference in results for participants.. The research design of this study used pre-experimental design in one group pretest - posttest design to know students' response in teaching reading by using oral presentation (Sudiati, Hanapi, \& Bugis, 2018). It means that the writer examined and analyzed the data, which were obtained after giving the treatment to the subject. In this case, the writer analyzed students' response in teaching reading after giving treatment by using oral presentation. This design is described as follows:

\begin{tabular}{llll} 
Group & Pre test & Treatment & Posts test \\
$\mathrm{A}$ & $\mathrm{O}_{1}$ & $\mathrm{X}$ & $\mathrm{O}_{2}$ \\
\cline { 3 - 3 } & &
\end{tabular}

. In this case, the populations of this study were all of the students of eleventh grade of SMAN 1 Suralaga in the school year of 2019/2020?, there are 35 students. Sample is representative amount of a population(Haddad et al., 2019). Another expert (Etikan, Musa, \& Alkassim, 2016)states that sample is some or part of investigated population. She also states that if the population is less than one hundred, it is better to take all of the population as the sample or subject of the research, but if the number of the population is more than one hundred, it is suggested to take $10-15 \%, 20-25 \%$ or more. Based on the statement above, the researcher take all of the eleventh grade students as the sample because less than one hundred students.

Instrument is a set of questions or exercise or other tools, which is used to measure the stage of intelligent, skill, knowledge, achievement and attitude of someone in the group of people(Phillips \& Phillips, 2016). This is absolutely needed to measure the achievement of the learners after teaching and learning process (Schulze \& Bosman, 2018). In this sense the researcher used a set of test in collecting the data.

In conducting this study, the researcher investigated the effect of students' oral presentation towards students' respond in reading text. Therefore, the researcher collected the data of the study by using test in form of oral questions. Then researcher asked the students to give respond based on the text given. This was aimed at knowing the students respond toward the reading text.

Online at https://journal.universitasbumigora.ac.id/index.php/humanitatis/

DOI $\quad:$ https://doi.org/10.30812/humanitatis.v7i2.1226 
In giving score toward the result of the students' respond, the researcher used score guidance. Firstly the researcher made key answer, and then the researcher checked the result of the students based on the key answer. The criteria that were used in correcting the result of the research were as in Table 1.

Table 1. The Scoring Guidance

\begin{tabular}{|c|c|c|}
\hline NO & SCORE & CRITERIA \\
\hline 1 & 5 & Very complete \\
\hline 2 & 4 & Complete \\
\hline 3 & 3 & Quite complete \\
\hline 4 & 2 & Not complete \\
\hline 5 & 1 & Not relevant \\
\hline
\end{tabular}

(Safari, 2003:23)

In this research, the data were obtained from the test in form of oral test. In collecting the data, the researcher gave the students some questions than the students gave their answer orally. The students were given the test twice. The students were given pre test to know their basic knowledge in reading text. After completing the pre-test, the writer treated the students with the same material, after that the writer completing the posts test.

\section{FINDING AND DISCUSSION}

The purpose of the study was to know is there an effect of the use of students' oral presentation in enhancing students' response in teaching reading. The research used pre-test and post-test as the instruments to collect the data. The test was oral test. The whole result of pre test and post test are presented in the following table:

Table 2. The result of pre test

\begin{tabular}{|l|l|l|l|}
\hline Score & Frequency & Total & Percent \\
\hline 12 & 3 & 36 & 7,73 \\
\hline 13 & 6 & 78 & 16.73 \\
\hline 15 & 5 & 75 & 16.09 \\
\hline 16 & 4 & 64 & 13.74 \\
\hline 17 & 5 & 85 & 18.25 \\
\hline 18 & 7 & 128 & 27.46 \\
\hline Total & 30 & 466 & 100 \\
\hline Mean & 15.22 & \multicolumn{3}{|l}{} \\
\hline Maximum & 18 & \multicolumn{3}{|l}{} \\
\hline Minimum & 12 & \multicolumn{3}{|l}{} \\
\hline
\end{tabular}

The mean score of the students in pre-test was 15.22 and the maximum score in the class was 18 while the minimum score of the class was 12 . The table above also shows that student who got 12 was 3 students (7.73\%). The students who got 13 were 6 students (16.73\%). The 
students who got 15 were 5 students $(16.09 \%)$. The students who got 16 were $4(13.74 \%)$. The students who got 17 were 5 students (18.25\%). The student who got 18 was 7 students (27.46\%).

Table 3. The result of post test

\begin{tabular}{|l|l|l|l|}
\hline \multicolumn{1}{|c|}{ Score } & Frequency & Total & Percent \\
\hline 18 & 4 & 72 & 8.05 \\
\hline 19 & 8 & 152 & 17.00 \\
\hline 20 & 8 & 160 & 17.89 \\
\hline 22 & 6 & 132 & 14.76 \\
\hline 23 & 6 & 138 & 15.43 \\
\hline Total & 30 & 894 & 100 \\
\hline Mean & 28.87 & & \\
\hline Maximum & 23 & & \\
\hline Minimum & 18 &
\end{tabular}

The mean score of the students in post-test was 28.87 and the maximum score in the class was 23 while the minimum score of the class was 18 . The table above also shows that student who got 24 was 1 student. The students who got 18 were 4 students. The students who got 19 were 8 students. The students who got 20 were 8 students. The students who got 22 were 6 students. The students who got 23 were 6 students.

After collecting and calculating obtained data that Oral Students' oral respond students respond in reading text was effective. It based on the big different gained between pre test and post test. The mean score of post test has greater achievement than pre test. It clearly indicated that the result of students in post test did the test much better that the students in pre test.

Based on the data gained, the score in pre-test the writer gained the lowest and highest score were 12 and 18. While the post-test obtained the lowest and the highest score were 18 and 23.. The calculation of the data had been conducted in which resulted the average (mean) in the pre test and posts test. The mean of the pre-test and post-test were and 15.22, while in posts test was 20.87The calculation of mean score and standard Deviation can be seen in Table 4. 
Table 4. The calculation of mean (X) and standard deviation (SD)

\begin{tabular}{|c|c|c|c|}
\hline \multicolumn{2}{|c|}{ Mean (X) } & \multicolumn{2}{c|}{ Standard Deviation } \\
\hline Pre-test & Post-test & Pre-test & Post-test \\
\hline 15.22 & 20.87 & 1.82 & 1.54 \\
\hline
\end{tabular}

To investigate the result of acquiring the students' respond toward reading text through students' oral presentation, the researcher used descriptive statistic for the categories in which consist of the ideal maximum score (SMi) was 25 and the ideal minimum score was 5. So, ideal mean score (Mi) gained was 15 and the ideal standard deviation (SDi) was 3.33.

The categories gained after calculating into the standard categories were as follow:

\begin{tabular}{|c|c|c|c|c|c|}
\hline MI & + & $1 \mathrm{SDI}$ to & MI & + & $3 \mathrm{SDI}$ is high \\
\hline 15 & + & $1(3.33)$ & 15 & + & $3(3.33)$ \\
\hline 15 & + & 3.33 & 15 & + & 9.99 \\
\hline 18.33 & & & 24.99 & & \\
\hline MI & - & $1 \mathrm{SDI}$ to & $<\mathrm{MI}$ & + & $1 \mathrm{SDI}$ is average \\
\hline 15 & - & $1(3.33)$ & 15 & + & $1(3.5)$ \\
\hline 15 & - & 3.33 & 15 & + & 3.33 \\
\hline 11.67 & & & 18.33 & & \\
\hline MI & - & $3 \mathrm{SDI}$ to & $<\mathrm{MI}$ & - & $1 \mathrm{SDI}$ is low \\
\hline 15 & - & $3(3.33) 15$ & - & $1(3.33)$ & \\
\hline 15 & - & 9.99 & 15 & - & 3.33 \\
\hline 5.01 & & & 11.67 & & \\
\hline
\end{tabular}

After collecting and calculating obtained data that oral students' respond in reading text was effective. It based on the big different gained between the result score of pre test and posts test. It can be seen on the mean score post-test gained from the some tests. The mean score of post tests has greater achievement than pre tests. Since the material of the test that had been presented in treatment by the same teacher and in the same length of the time.

The computation of mean score of pre test and post test resulted the figure of 19.75 this figure was resulted to the value $\mathrm{df}=44$. $\mathrm{Tt}$ on the table $\mathrm{df}=44$ was 2.021. After distinguish the both $\mathrm{t}$-value, so t-test was greater than t-table with indicating the different were very significant. This means that the treatment by using students ' oral presentation toward students' respond in reading text, there was a positively significant change 


\section{CONCLUSION}

Based on the result of the data analysis and the discussion in the previous chapter, the researcher can make conclusion that there was effect of the students' oral presentation toward students' respond in reading text. The result can be seen from the result of data analysis which is indicated that the figure of the mean score in posts test was 20.87 and for pre test was 15.22 . The deviation scores for posttest was 1.54 and pre test was 1.69, where the highest score of post test 23 and the lowest score was 18 and the highest score of pre-test was 18 and the lowest score was 12.

From the explanation above, it can be concluded that there were significant differences of scores which were gotten by students between pretest and posttest. It means that the treatment given the students was significant to improve the student's response in teaching reading by oral presentation.

\section{REFERENCES}

Anderson, R. C. (2018). Role of the reader's schema in comprehension, learning, and memory. In Theoretical Models and Processes of Literacy (pp. 136-145). Routledge.

Etikan, I., Musa, S. A., \& Alkassim, R. S. (2016). Comparison of convenience sampling and purposive sampling. American Journal of Theoretical and Applied Statistics, 5(1), 1-4.

Gilles, C., Wang, Y., Smith, J., \& Johnson, D. (2013). "I'm No Longer Just Teaching History." Professional Development for Teaching Common Core State Standards for Literacy in Social Studies: By Identifying the Reading Strategies They Regularly Use within Their Disciplines, Content Area Teachers Are Better Able to Teach Students How to Derive Meaning from Texts. Middle School Journal, 44(3), 34-43.

Haddad, C., Obeid, S., Akel, M., Honein, K., Akiki, M., Azar, J., \& Hallit, S. (2019). Correlates of orthorexia nervosa among a representative sample of the Lebanese population. Eating and Weight Disorders-Studies on Anorexia, Bulimia and Obesity, 24(3), 481-493.

Haerudin, D., Koswara, D., \& Sejati, A. (2021). Content Gradation OF Sundanese Textbooks for Junior High School and Senior High School (Review Of Facts, Concepts, Principles, and Procedures in The Field of Sundanese Language Study in 2013 Local Content Curriculum Revised 2017). Journal of Education, Teaching and Learning, 6(1), 39-46.

Matsuda, A. (2017). Preparing teachers to teach English as an international language. Multilingual Matters.

Merriam, S. B., \& Tisdell, E. J. (2015). Qualitative research: A guide to design and implementation. John Wiley \& Sons.

Moser, A., \& Korstjens, I. (2018). Series: Practical guidance to qualitative research. Part 3: Sampling, data collection and analysis. European Journal of General Practice, 24(1), 9-18.

Phillips, J. J., \& Phillips, P. P. (2016). Handbook of training evaluation and measurement methods. Routledge.

Saputra, A., Sutarman, \& Syamsurrijal. (2020). Designing Life Skill - Based English Reading Materials For Second Grade Students Of SMA Negeri 1 Pringgasela. Journal of Dedicators Community UNISNU Jepara, 4(1), 297-322. https://doi.org/https://doi.org/10.30812/humanitatis.v6i2.793

Online at https://journal.universitasbumigora.ac.id/index.php/humanitatis/

DOI $\quad:$ https://doi.org/10.30812/humanitatis.v7i2.1226 
Schulze, S., \& Bosman, A. (2018). Learning style preferences and Mathematics achievement of secondary school learners. South African Journal of Education, 38(1), 1-8.

Sepyanda, M. (2017). The importance of English subject in elementary school curriculum. English Language Teaching and Research, 1(1).

Sudiati, S., Hanapi, H., \& Bugis, R. (2018). The Effectiveness of Think Aloud Strategy in Students' Reading Achievement. Jurnal Retemena, 5(1), 44-56.

Toro, V., Camacho-Minuche, G., Pinza-Tapia, E., \& Paredes, F. (2019). The Use of the Communicative Language Teaching Approach to Improve Students' Oral Skills. English Language Teaching, 12(1), 110-118. 